\title{
The dietary intake and activities of an Alaskan mountaineering expedition
}

\author{
By J. D. KINLOCH \\ (Medical Officer to the 1956 Parachute Brigade Alaska Expedition) \\ The Royal Infirmary and Belvidere Hospital, Glasgow
}

(Received 29 Fuly 1958)

There are few records of the calorie intake and energy expenditure of expeditions in the field. A trained physiologist is not usually available and, however desirable ancillary scientific investigations may be, the chance of achieving the primary objective of the expedition must not be jeopardized. It is so particularly with mountaineering expeditions.

In 1956 , an expedition was made by a four-man party from the I6th (British) Independent Parachute Brigade to the McKinlay Range of mountains in Alaska. This expedition, the first British mountaineering expedition to visit Alaska, was led by Captain E. J. E. Mills, Royal Army Service Corps (R.A.S.C.) and has been described by him elsewhere (Mills, I957). Its main object was to explore an unknown glacier system and its surrounding peaks. Throughout the 6 weeks from 26 May to 6 July 1956, while the party was in the mountains and entirely self-supporting, the food consumption and daily activities of the individual climbers were studied.

An accurate assessment of the dietary intake was facilitated by the simplicity of the rationing system, the length of the study, and the reasonably close medical supervision throughout the entire period.

By checking body-weights at intervals it was possible to assess whether or not an individual was in approximate metabolic balance.

As a rough guide to energy expenditure, records were made, by a diary technique, of all daily activities. It was not possible to take a respirometer to make accurate measurements of energy expenditure by indirect calorimetry. Not only would porterage have been a problem, but the inherent difficulties of an arduous climbing expedition precluded the use of such a method.

\section{EXPERIMENTAL}

\section{The expedition}

Composition. The members of the expedition were all trained parachutists and as such were of above average fitness. Their selection was based primarily on their mountaineering experience. Details of physique are given in Table I. Each member of the expedition was delegated specific tasks: the leader (J. M.) was responsible for all organization and day-to-day planning, and, in addition, collected specimens for a geological survey; the second-in-command (W.D.) was the accountant and meteorologist; the medical officer (D. K.) was responsible for health and ration 
administration; the fourth member of the party (D.P.) was the official expedition photographer and artist.

Itinerary. Exploration of Alaskan mountains presents not only the complexities of Arctic travel, but in addition the difficulties of Alpine climbing. Every peak is icecapped and every valley over $2000 \mathrm{ft}$. in altitude is glaciated. As a result, any exploration party endeavouring to gain access to the mountains encounters considerable preliminary difficulty on the glaciers, which, because of Arctic weather conditions and steep gradients, are rapidly moving and consequently heavily crevassed.

Table r. Ages, heights, weights and surface areas of the climbers

$\begin{array}{lcccc} & \text { D.K. } & \text { J.M. } & \text { W.D. } & \text { D.P. } \\ \text { Age (years) } & 26 & 29 & 29 & 24 \\ \text { Height (cm) } & 176 & 175 & 185 & 171 \\ \text { Surface area (m²) } & 1 \cdot 85 & 1 \cdot 80 & 2 \cdot 06 & 1 \cdot 77 \\ \text { Body-weight (kg): } & & & & \\ \text { Initially, Ist day } & 68 \cdot 6 & 65 \cdot 0 & 79 \cdot 5 & 68 \cdot 2 \\ \text { At end of period I (glacier), Ioth day } & 69 \cdot 2 & 65 \cdot 5 & 78 \cdot 6 & 65 \cdot 0 \\ \text { At end of period 2 (climbing), I 5th day } & 69 \cdot 2 & 65 \cdot 0 & 76 \cdot 9 & 67 \cdot 8 \\ \text { At end of period 3 (glacier), 22nd day } & 68 \cdot 2 & 64 \cdot 4 & 77 \cdot 3 & 65 \cdot 5 \\ \text { At end of period 4 (climbing), 32nd day } & 68 \cdot 6 & 64 \cdot 6 & 77 \cdot 7 & 65 \cdot 5 \\ \text { At end of periods 5-6 (glacier and climbing), 39th day } & 68 \cdot 2 & 64 \cdot 6 & 79 \cdot 5 & 65 \cdot 5 \\ \text { At end of period 7 (glacier), 4Ist day } & 69 \cdot 7 & 64 \cdot 6 & 77 \cdot 7 & 65 \cdot 9 \\ \text { Mean } & 68 \cdot 8 & 64 \cdot 6 & 78 \cdot 2 & 66 \cdot 4\end{array}$

It was at the foot of one of these unexplored glacier systems, the Traleika glacier, that a U.S.A.A.F. helicopter set down the expedition, along with its $1000 \mathrm{lb}$. (450 kg) of supplies and equipment. These had to be transported up some 20 miles of heavily crevassed glacier by back packing and sledge hauling; neither dog teams nor porters were available.

The altitude of the glacier traversed was between 5000 and $7000 \mathrm{ft}$. (I600 and $2100 \mathrm{~m}$ ). From a base camp on the glacier, four virgin peaks, of heights between I I,000 ft. $(3300 \mathrm{~m})$ and I $3,000 \mathrm{ft}$. $(3900 \mathrm{~m})$ were climbed; the ascent of these mountains usually necessitated one or two camps on the way to the summit, the final assaults being launched from cols at a height of $10,000 \mathrm{ft}$. (3000 $\mathrm{m})$. Setting up the high camps was invariably a slow business; weaving a route through icefalls and climbing steep ice slopes, often with step-cutting, whilst heavily laden, was no easy task.

One of the great advantages of climbing in Alaska is that there is continuous daylight in summer and the programme for the day is determined by the snow conditions and not by the clock. The climate in Alaskan mountains is one of extremes. The temperatures range from $0^{\circ} \mathrm{F}\left(-18^{\circ} \mathrm{C}\right)$ at midnight to $80^{\circ} \mathrm{F}\left(27^{\circ} \mathrm{C}\right)$ at noon when the glacier basin greatly intensifies the effects of the sun's rays. On the average, however, temperatures in the very early morning were between $20^{\circ}$ and $25^{\circ} \mathrm{F}$, so, whenever possible, all climbing and marching were done at this time. Because temperatures were below freezing, the danger from avalanches and the bridging of crevasses was minimized and, in addition, sledge hauling and load carrying were facilitated.

Fresh snow provided a further complication, but on only 6 days was climbing actually prevented by heavy snowfall, although load transporting was considerably hampered on many occasions by several feet of soft snow on the glacier. 


\section{Investigation}

Records. Each individual received daily a form for recording activity and food consumption. In order to overcome the difficulties caused by the constant daylight and the complete irregularity of eating and sleeping times, the form covered a 'ration day' -from after breakfast till after breakfast-these periods ranging from $\mathrm{I} 2$ to $30 \mathrm{~h}$. Exact times of all activities and meals were noted, and results were later converted to show the dietary intake and activity of individuals for $24 \mathrm{~h}$ periods; these periods were taken from midday to midday, which often coincided with a 'ration day'.

Rations. There were four basic types of ration, all designed for the use of isolated Army units in the field, but equally suitable for any small mountaineering expedition.

A 'compo' type of ration (Table 2), designed specially for the expedition, provided the bulk of the food supply. It was simple in composition and of low cost; the ratio

Table 2. (A) Contents of a man-day ration from a $2 \times 8$ man-day standard ration pack and a 4 man-day emergency ration pack and $(B)$ extra luxury items for the whole expedition

\begin{tabular}{|c|c|c|c|c|c|c|}
\hline & \multicolumn{3}{|c|}{$A$ (all values in oz.) } & \multirow[b]{2}{*}{ Type C } & \multirow[b]{2}{*}{ Type D } & \multirow{2}{*}{$\begin{array}{c}\text { Emergency } \\
\text { ration }\end{array}$} \\
\hline & \multicolumn{2}{|r|}{ Type A } & Type B & & & \\
\hline Pemmican & \multicolumn{2}{|r|}{2} & - & 一 & - & - \\
\hline Corned beef & \multicolumn{2}{|r|}{ - } & 3 & - & - & 一 \\
\hline Stewed steak & \multicolumn{2}{|r|}{ - } & - & 4 & - & - \\
\hline Luncheon meat & \multirow{2}{*}{\multicolumn{2}{|c|}{$\overline{1}_{\frac{1}{8}}$}} & - & - & 2 & - \\
\hline Sardines & & & - & - & $\mathrm{I} \frac{1}{8}$ & - \\
\hline Cheese & \multirow{2}{*}{\multicolumn{2}{|c|}{$\overline{3}$}} & 2 & 2 & - & - \\
\hline Porridge oats & & & - & 3 & 3 & $1 \frac{1}{2}$ \\
\hline Grapenuts & \multicolumn{2}{|r|}{$\underline{-}$} & $\mathrm{I}+1$ & - & - & - \\
\hline Nut pemmican & \multicolumn{2}{|r|}{ 一 } & - & - & - & 2 \\
\hline Soup & & - & - & - & - & $\frac{1}{2}$ \\
\hline Mint cake (Kendal) & \multicolumn{2}{|r|}{-} & - & - & - & 2 \\
\hline Cake (fruit) & \multicolumn{2}{|r|}{2} & - & - & 2 & - \\
\hline Steamed pudding & \multicolumn{2}{|r|}{ 一 } & $2 \frac{1}{2}$ & $2 \frac{1}{2}$ & - & - \\
\hline Glucose tablets (Ho & \multicolumn{2}{|l|}{ lergade) } & - & 一 & - & $\frac{3}{4}$ \\
\hline \multicolumn{3}{|c|}{ Orangeade powder (Army) } & - & - & 一 & 2 \\
\hline \multirow{2}{*}{$\begin{array}{l}\text { Sugar } \\
\text { Condensed milk }\end{array}$} & \multirow{2}{*}{\multicolumn{5}{|c|}{$\begin{array}{l}4 \\
1 \frac{1}{2}\end{array}$}} & 4 \\
\hline & & & & & & - \\
\hline Tea & \multirow{2}{*}{\multicolumn{5}{|c|}{$\begin{array}{r}\frac{1}{4} \\
1 \frac{7}{8}\end{array}$}} & - \\
\hline Butter & \multirow{2}{*}{\multicolumn{5}{|c|}{$\begin{array}{l}1 \frac{7}{8} \\
3\end{array}$}} & - \\
\hline Biscuits (Army) & & & & & & - \\
\hline Biscuits (sweet) & \multicolumn{5}{|c|}{2} & - \\
\hline Chocolate & \multicolumn{5}{|c|}{$\begin{array}{l}4 \\
2\end{array}$} & 2 \\
\hline Sweets & \multirow{2}{*}{\multicolumn{5}{|c|}{2}} & - \\
\hline Fudge (Horlick's) & & & & & & 2 \\
\hline \multicolumn{7}{|c|}{$B$ (except soup, all values in lb.; total weight $60 \mathrm{lb}$. ) } \\
\hline Soup & \multirow{2}{*}{\multicolumn{2}{|c|}{16 (packets) }} & \multicolumn{3}{|c|}{ Preserves (various) } & 2 \\
\hline Meat bars & & & dge & & & 2 \\
\hline Dried vegetable & I & & gar & & & 2 \\
\hline Dried potato & 4 & & ta-Wheat & & & 8 \\
\hline Baked beans & 4 & & verages $(v$ & ious) & & 6 \\
\hline Rice & 2 & & blets (Hor & ck's and $\mathrm{C}$ & valtine) & 4 \\
\hline Nut pemmican & 3 & & anut butte & & & 2 \\
\hline Dried fruit & 6 & & D. butter & oncentrate & & 3 \\
\hline Tinned fruit & 6 & & & & & 2 \\
\hline
\end{tabular}


of calorie value to bulk and gross weight was good, and a European type of diet was provided. The design permitted considerable ease in packing, transportation and distribution. Four variations, ration types $\mathrm{A}, \mathrm{B}, \mathrm{C}$ and $\mathrm{D}$, made the ration more acceptable over a long period. Most foods were tinned or dried and obtainable at any general provision store. Vacuum-packed foods were excluded on grounds of cost. The rations were packed in standard R.A.S.C. sleeve-type boxes, each having a gross weight of $35 \mathrm{lb}$. ( $16 \mathrm{~kg}$ ) and containing two 8 man-day units. A daily ration of 26-30 oz. (730-840 g) net of food per man was provided with a caloric value averaging 3370 Cal. at a cost of 4 s. 3 d. (Table 3 ).

Table 3. Protein, fat, carbohydrate and calorie yield/man/day and daily cost/man of the rations used on the expedition*

\begin{tabular}{|c|c|c|c|c|c|c|c|}
\hline Ration & $\begin{array}{l}\text { No. of } \\
\text { days } \\
\text { used }\end{array}$ & $\begin{array}{l}\text { Protein } \\
\text { (g) }\end{array}$ & $\begin{array}{l}\text { Fat } \\
\text { (g) }\end{array}$ & $\begin{array}{l}\text { Carbo- } \\
\text { hydrate } \\
\text { (g) }\end{array}$ & $\begin{array}{c}\text { Energy } \\
\text { (Cal.) }\end{array}$ & $\begin{array}{l}\text { Weight } \\
\text { (g) }\end{array}$ & Cost \\
\hline \multicolumn{8}{|l|}{ Standard ration: } \\
\hline Type A & 12 & 60 & I 50 & 480 & 3490 & $75^{\circ}$ & $4 s .7 d$. \\
\hline Type B & 8 & 55 & 160 & 440 & $337^{\circ}$ & 770 & $4 s \cdot 3 d$ \\
\hline Type C & 6 & 60 & 175 & 470 & 3710 & 840 & 3s. IId. \\
\hline Type D & 2 & 50 & I 50 & 460 & $335^{\circ}$ & 750 & 3s. Iod. \\
\hline Emergency & 2 & 15 & 60 & 330 & 1920 & 470 & $2 s .6 d$ \\
\hline Army 'Snow't & 4 & 140 & Igo & 460 & 4170 & 980 & $>$ IOs. \\
\hline Army G.S. Mk V† & 5 & 98 & 140 & 550 & 3860 & 1230 & $>$ Ios. \\
\hline
\end{tabular}

* The composition was calculated from the manufacturer's figures and the standard tables of the Ministry of Food (I95I) based on those of the Medical Research Council: Accessory Food Factors Committee (1945).

$\uparrow$ See below.

In addition there were for the whole expedition $60 \mathrm{lb} .(27 \mathrm{~kg})$ of luxury items. Part of these had to be used to eke out the normal rations for 4 days and some provided emergency pocket rations of fudge and glucose tablets for each climber. The remainder provided a daily supplement of $4 \mathrm{Oz}$. ( $112 \mathrm{~g}$ ) of assorted foods per man. Luxury items were distributed, as far as possible, on demand, each individual receiving the same quantity; they added considerable variety to the daily ration in the way of preserves, extra fruit and vegetables, biscuits and sweets, and a selection of beverages. There was a 5 days' supply of Army 24 Hour Ration Packs G.S. Mk V and a 4 days' supply of Army 24 Hour Snow Rations (a $5^{\text {th }}$ day's supply being consumed by a predatory raven). These rations were very convenient in use and were considered comparatively luxurious; they had the disadvantages of greater weight and expense and the G.S. Mk. V Ration was considerably more bulky than the standard expedition ration. A 2-day supply of small light-weight emergency rations was also carried.

Food intake. As mentioned earlier, the simplicity of the rations greatly assisted the individual in recording his food consumption. On his form he would note the type of ration issued for the day, and any extra items consumed or left over; the extra items were usually chocolate, sweets and biscuits and the weights were therefore readily estimated.

A record was also kept of all fluid intake. Mugs were marked off in measures to assist estimation of fluid. Water was obtained from pools in the central moraine of the 
lower glacier but at the high camps snow, or, where possible, ice was melted over paraffin pressure stoves or, occasionally, melted in a heat-absorbing container, e.g. a black plastic cape, laid out in the sun. As in any climbing expedition, a certain amount of artificiality must have occurred in providing for the fluid and calorie intake since each man was issued with his daily ration, which meant that supply was not necessarily related to demand. A man could either hand over his unwanted food to a communal pool or store more suitable items, such as sweets, until a later occasion. On the whole, however, each man tended to take what was put before him-not always eating merely on account of hunger or a good appetite, but eating for the sake of eating as is the wont of civilized races. This habit is particularly noticeable on an arduous mountaineering expedition where eating and sleeping are two of the main joys in life.

Physical activities. Each man noted on his form the time spent on different activities throughout the day; these activities were classified under the three main headings of sleeping (including resting within sleeping bags), minor activity (either within tents or around camp), and exertion (including climbing and marching).

The estimates of sleeping and resting were combined since the true sleeping time was reduced on an average to about $50 \%$ of the attempted sleeping time because of such factors as fatigue, altitude, overcrowded tents at high camps, and the extremes of heat and cold experienced during the usual afternoon and evening sleeping period.

Minor activity included all the incidental daily tasks of any expedition from dressing, cooking and mending within tents to performing one's toilet, carrying water, pitching and striking camp, and photography around the camp site. All minor activity around the camp site, however, was restricted to a radius of some ro yd. because of the constantly present danger of hidden crevasses.

For climbing and marching a record was kept of terrain, distances, heights and loads, in addition to timings; all rest periods of more than a minute or two, and halts for food, were deducted and included under minor activity.

A useful cross-check on timings was provided by the fact that, apart from minor activity, the whole party was almost invariably doing the same thing at any one time.

Body-weights (Table I). Body-weights were recorded at intervals by means of a spring balance (0-100 kg) suspended from an ice axe, the subject sitting on a rope sling attached to the hook of the balance. No opportunity occurred to calibrate the balance accurately throughout its entire range but comparison with two other weighing machines (of lever and spring type respectively) revealed a variation of less than I $\mathrm{kg}$ for the weights recorded.

\section{RESULTS}

\section{Dietary intake}

The mean daily calorie intake and hours of activity are shown in Table 4.

The 6 weeks spent on the expedition are broken into seven periods according to whether the major activity was glacier marching or actual climbing. The mean calorie intake for each period is shown in Table 4 , together with mean calorie intakes for all the days spent either marching on the glacier, climbing or resting. The mean intakes for the whole period of the expedition are given in Table 7 . 
Table 4. Daily calorie intake and hours of activity of the members the expedition

\begin{tabular}{|c|c|c|c|c|c|c|}
\hline \multirow[b]{2}{*}{ Period } & \multirow[b]{2}{*}{ Day no. } & \multirow[b]{2}{*}{ Activity } & \multirow[b]{2}{*}{$\begin{array}{l}\text { Calorie } \\
\text { intake } \\
\text { (Cal.) }\end{array}$} & \multicolumn{3}{|c|}{ Hours spent daily in } \\
\hline & & & & Exertion & Sleep & $\begin{array}{c}\text { Minor } \\
\text { activities }\end{array}$ \\
\hline \multirow[t]{11}{*}{$\mathbf{r}$} & I & Glacier & 3825 & 3 & 9 & 12 \\
\hline & 2 & Glacier & $363^{\circ}$ & 6 & 8 & 10 \\
\hline & 3 & Glacier & 2850 & 4 & 9 & II \\
\hline & 4 & Glacier & $345^{\circ}$ & 7 & $6 \frac{1}{2}$ & $10 \frac{1}{2}$ \\
\hline & 5 & Glacier & 3920 & $7 \frac{1}{2}$ & 9 & $7 \frac{1}{2}$ \\
\hline & 6 & Glacier & 3470 & $8 \frac{1}{2}$ & $3^{\frac{1}{2}}$ & 12 \\
\hline & 7 & Glacier & 3465 & 5 & 10 & 9 \\
\hline & 8 & Glacier & 3525 & 5 & 9 & 10 \\
\hline & 9 & Rest day & 4120 & - & I I & I3 \\
\hline & Io & Rest day & $435^{\circ}$ & - & 9 & I5 \\
\hline & Mean & & 3640 & $4 \frac{1}{2}$ & $8 \frac{1}{2}$ & II \\
\hline \multirow[t]{6}{*}{2} & II & Climbing* & 3240 & II & 2 & II \\
\hline & 12 & Climbing* & 1080 & 3 & 9 & I2 \\
\hline & I3 & Climbing* & 3795 & $8 \frac{1}{2}$ & $6 \frac{1}{2}$ & 9 \\
\hline & I4 & Rest day & 3390 & - & 14 & I0 \\
\hline & 15 & Climbing* & 3420 & Io & 4 & Io \\
\hline & Mean & & 2985 & $6 \frac{1}{2}$ & 7 & $10 \frac{1}{2}$ \\
\hline \multirow[t]{8}{*}{3} & 16 & Glacier: rest day & 4770 & - & 15 & 9 \\
\hline & I 7 & Glacier $\dagger$ & $43^{10}$ & 8 & 6 & 10 \\
\hline & 18 & Glacier & 3620 & 7 & 8 & 9 \\
\hline & I9 & Glacier & 3940 & $5 \frac{1}{2}$ & 6 & $12 \frac{1}{2}$ \\
\hline & 20 & Glacier & 3390 & 5 & 8 & II \\
\hline & $2 I$ & Glacier & 3015 & - & 13 & II \\
\hline & 22 & Glacier & 5000 & 3 & 7 & 14 \\
\hline & Mean & & 4010 & 4 & 9 & II \\
\hline \multirow[t]{11}{*}{4} & 23 & Climbing* & 4320 & 8 & 4 & 12 \\
\hline & 24 & Rest day & 2600 & 一 & 12 & 12 \\
\hline & 25 & Climbing* & 4865 & $6 \frac{1}{2}$ & 5 & $12 \frac{1}{2}$ \\
\hline & 26 & Rest day & 3035 & - & 9 & I5 \\
\hline & 27 & Climbing & 3500 & 4 & 12 & 8 \\
\hline & 28 & Rest day & 4105 & - & 13 & II \\
\hline & 29 & Climbing & 2670 & 7 & I 1 & 6 \\
\hline & 30 & Climbing & 3655 & 8 & 7 & 9 \\
\hline & $3 \mathrm{I}$ & Climbing & 2585 & 7 & 9 & 8 \\
\hline & 32 & Climbing* & 3800 & 9 & 8 & 7 \\
\hline & Mean & & 3515 & 5 & 9 & 10 \\
\hline \multirow[t]{6}{*}{5} & 33 & Glacier $\dagger$ & $544^{\circ}$ & 5 & 7 & 12 \\
\hline & 34 & Glacier & 5745 & 6 & 8 & I0 \\
\hline & 35 & Glacier & 3820 & 8 & 7 & 9 \\
\hline & 36 & Glacier & 3740 & $6 \frac{1}{2}$ & 8 & $9 \frac{1}{2}$ \\
\hline & 37 & Glacier & 4855 & $\mathrm{I}_{\frac{1}{2}}$ & $x \times \frac{\frac{1}{2}}{2}$ & II \\
\hline & Mean & & 4720 & $5 \frac{1}{2}$ & $8 t$ & I0t \\
\hline \multirow[t]{3}{*}{6} & 38 & Climbing* & & $13 \frac{1}{2}$ & 6 & $4 \frac{1}{2}$ \\
\hline & 39 & Climbing* & 4105 & $4 \frac{1}{2}$ & 9 & $10 \frac{1}{2}$ \\
\hline & Mean & & 4250 & 9 & $7 \frac{1}{2}$ & $7 \frac{1}{2}$ \\
\hline \multirow[t]{3}{*}{7} & 40 & Glacier & 5875 & II & 4 & 9 \\
\hline & 41 & Glacier & 4265 & $12 \frac{1}{2}$ & 5 & $6 \frac{1}{2}$ \\
\hline & Mean & & $5 \circ 70$ & 12 & $4 \frac{1}{2}$ & $7^{\frac{1}{2}}$ \\
\hline
\end{tabular}

Loads carried: Usual load whilst climbing, under ro $\mathrm{lb}$. $(4.5 \mathrm{~kg})$. Usual load on glacier, $30-80 \mathrm{lb}$. ( $13-36 \mathrm{~kg}$ ) with sledge hauling $220-320 \mathrm{lb}$. (100-150 kg).

* Load whilst climbing, $30-70 \mathrm{lb}$. ( $13-32 \mathrm{~kg})$.

$\dagger$ Load on glacier, under ro $\mathrm{lb} .(4.5 \mathrm{~kg})$. 


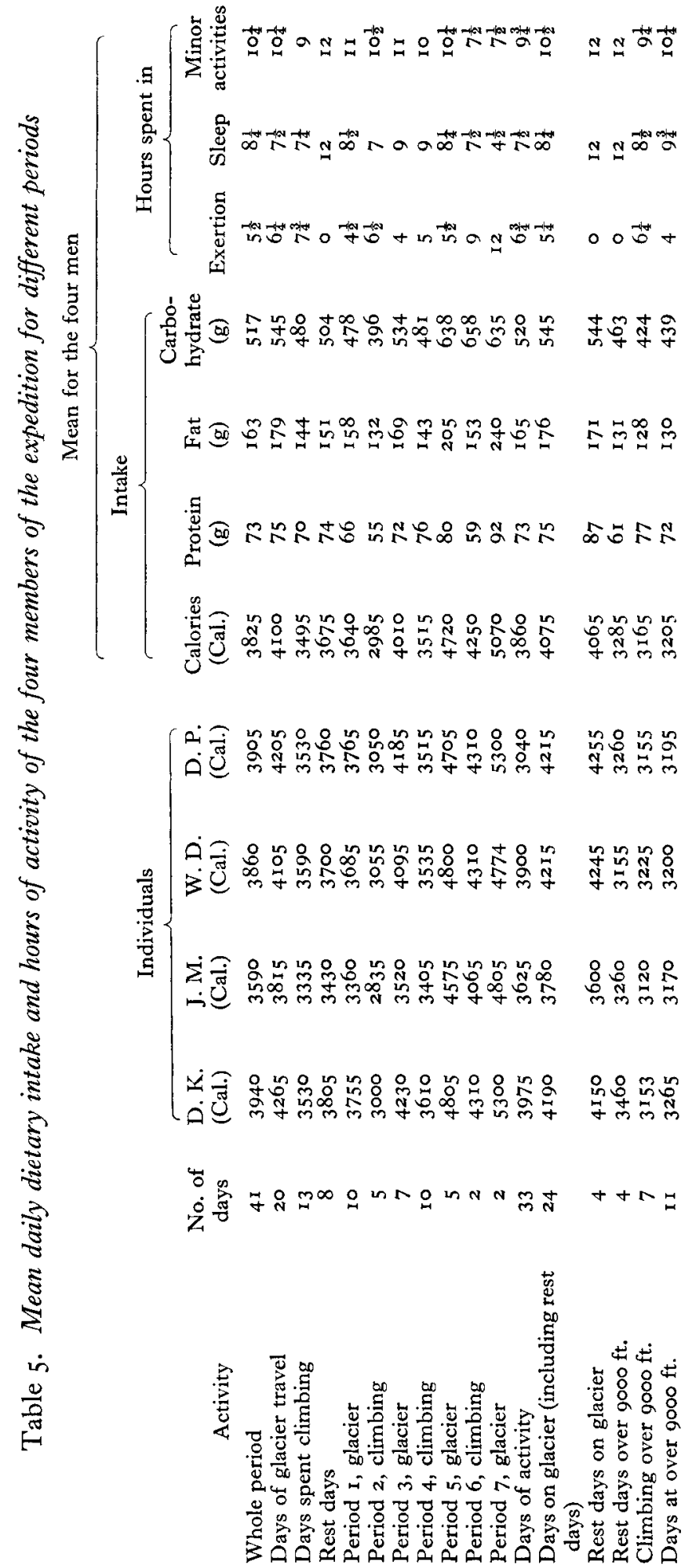


In Table 5 a further breakdown of the diet is shown giving the mean consumption of protein, fat and carbohydrate for the various periods, and for further subdivided types of activity.

The calorie intake whilst climbing was considerably lower $(3495 \mathrm{Cal}$.) than that on the glacier (4100 Cal.), save in the last climbing period, which was an $\mathrm{I} 8 \mathrm{~h}$ mountain ascent from a base camp on the glacier. Although exertion whilst climbing was always considerably more strenuous than that on glacier marches, the calorie intake was thought to be lower primarily because the weights of the loads to be carried, and hence the rations issued, were reduced to facilitate climbing under difficult conditions, as on steep ice slopes. Further contributing factors to the low calorie intake were the physical and mental fatigue after a strenuous day's climbing which reduced the desire both to cook and to eat food, sleep often being preferred.

The highest calorie intake was recorded on days spent traversing the glacier (4100 Cal.) although it was almost identical to the mean intake for rest days on the glacier $(4065$ Cal.). The overall mean for rest days was reduced to $3675 \mathrm{Cal}$. because some rest days were enforced by inclement weather at the camps at $10,000 \mathrm{ft}$. where rations were short.

The highest calorie intake for any one day $(5875 \mathrm{Cal}$.) was on the final march down the glacier, during which the party, each man carrying an $80 \mathrm{lb} .(36 \mathrm{~kg})$ pack, was on the move for 24 of the last $36 \mathrm{~h}$ spent in the mountains, gorging themselves at their food depots en route, as they hastened to keep a date with a helicopter in the foothills.

An emergency bivouac after a mishap at the end of a difficult icefall ascent brought about the lowest daily calorie intake ( $1080 \mathrm{Cal}$.) of the expedition as a result of a ration shortage and the general fatigue of the party.

The mean individual intakes throughout the expedition, over a period of $4 \mathbf{I}$ days, showed, on the whole, no great variation. Two members of the party (D.K. and D. P.) tended to feel the need for every morsel of food provided, and they had the highest intake (over $3900 \mathrm{Cal}$.). The other two were more restrained, although the most heavily built individual (W. D.) had almost as high an intake ( $3860 \mathrm{Cal}$.). J. M., however, consistently and noticeably ate less $\left(359^{\circ} \mathrm{Cal}\right.$.) than the others and frequently did not consume his entire ration.

The mean individual intakes of protein, fat and carbohydrate showed only slight variations in quantity and proportions. There was no consistent alteration in proportions for any particular type of activity or with increased altitude.

Protein provided only $8 \%$ of the total calorie intake, which is below the minimum of I $\%$ recommended by the British Medical Association: Committee on Nutrition (I950). The low protein intake was mainly due to the composition of the standard expedition ration; the desire for more meat was indeed felt by individuals and there was little adequate protein supplement in the luxury boxes. Another oz. $(28 \mathrm{~g})$ of high-protein food/man/day in the basic ration would have been a most desirable addition.

The intake of vitamins and calcium also did not meet the recommended B.M.A. standards, as is shown in Table 6. An important contribution to this intake was made 
by the luxury items. However, a compound vitamin capsule was consumed daily and, besides providing adequate vitamins, it had a marked psychological effect on individuals who felt they might be deprived of adequate nutrition.

Pemmican was the only item in the ration not normally consumed in a European diet; although well tolerated, it was received unenthusiastically and meat bars would have been preferred. Dried soups were, whenever possible, added to the ration from the luxury boxes. These, with nutritive tablets such as Horlick's or Ovaltine tablets, would seem to be most acceptable for any expedition in Arctic or sub-Arctic climates. The generous daily rations of chocolate and butter were fully appreciated and between them provided over $1000 \mathrm{Cal} . /$ day.

Table 6. Mean daily intake/man of vitamins and minerals of the four members of the expedition

$\begin{array}{lcccc}\text { Standard } & \begin{array}{c}\text { Standard } \\ \text { rations } \\ \text { rations }\end{array} & \begin{array}{c}\text { Vitamin* } \\ \text { capsule } \\ \text { items } \\ \text { taken in } \\ \text { addition }\end{array} & \begin{array}{c}\text { Recommended } \\ \text { allowance }\end{array} \\ \text { Vitamin A (i.u.) } & 2517 & 4360 & 5000 & 2500 \\ \text { Thiamine ( } \mu \mathrm{g}) & 672 & 1200 & 3000 & 1600 \\ \text { Riboflavin }(\mu \mathrm{g}) & 784 & 1500 & 3000 & 1800 \\ \text { Nicotinic acid (mg) } & 4 \cdot 8 & 12 & 20 & 16 \\ \text { Ascorbic acid (mg) } & 1 \cdot 5 & 13 & 75 & 20 \\ \text { Vitamin D (i.u.) } & 215 & 340 & 500 & 150 \\ \text { Calcium (mg) } & 420 & 500 & - & 800 \\ \text { Iron (m) } & 27 & 28 & & 12\end{array}$

* Vimagna, a compound vitamin capsule (Lederle Laboratories Ltd).

+ British Medical Association: Committee on Nutrition (1950), recommended allowance for a 4000 Cal. diet.

The fluid intake varied little from one individual to another and averaged $4 \mathrm{pt}$. $\left(2 \cdot 3\right.$ 1.) daily; above $9000 \mathrm{ft}$. ( $1700 \mathrm{~m}$ ) the mean dropped to $3 \frac{1}{2} \mathrm{pt}$. $(2 \cdot 01$.). This amount was considerably less than the mean of $5^{-7}$ pt. $\left(2 \cdot 8-4^{\cdot 0} 1\right.$.) of fluid consumed daily by members of the Everest expedition (Pugh, 1954).

\section{Energy expenditure and daily activity}

There was considerable variation in the times and duration of the various activities from day to day, as shown in Table 4. It was due to the $24 \mathrm{~h}$ of daylight, the only factors restricting activity being the snow and weather conditions. All periods of time spent in the various activities were essentially the same for each member of the expedition, apart from differences of $\mathrm{r}-2 \mathrm{~h}$ on only three occasions. The heavily crevassed glaciers required that the whole party be roped together on all occasions whilst on the move.

On the glacier, marching time varied from $\mathrm{I}$ to $\mathrm{I} 8 \mathrm{~h}$ at any one stretch and climbing time from 3 to $\mathrm{I} 8 \mathrm{~h}$.

Hours of sleep (which included hours spent awake in sleeping bags) varied from 2 on a climbing day to ${ }_{5}$ on a rest day. The mean daily sleeping time for the expedition was $8 \frac{1}{4} \mathrm{~h}$, which agrees with the observations of Lewis \& Masterton (I957) on the 
North Greenland expedition that, despite the irregularity of sleep, the overall mean approximated to the time normally spent asleep in civilization.

Loads carried by individuals varied widely. On the glacier, in the process of relaying supplies, the average load was between 30 and $40 \mathrm{lb}$. ( $13-18 \mathrm{~kg}$ ) back packed, with limits of $20-80 \mathrm{lb} .(9-36 \mathrm{~kg})$; in addition three men were usually sledge-hauling, whilst the fourth probed for crevasses. On the actual summit assaults, under ro lb. $(4.5 \mathrm{~kg})$ were carried, but on the ascent to the high camps the loads were $50-70 \mathrm{lb}$. $(22-32 \mathrm{~kg})$. It had been hoped, with an accurate note of loads, heights and distances for each individual, to make some estimate of energy expenditure and to draw a comparison with daily food consumption. Such an estimate would, however, be almost entirely guesswork owing to the wide variety of conditions encountered, ranging from simple marching to the ascent of icefalls and the extraction of men from crevasses. Therefore only the overall times spent by the party in the three main activitiesclimbing and marching, minor duties and sleeping-have been tabulated (Tables 4 and 5).

\section{Health}

Throughout the expedition health was excellent. The only demands made on the medicine chest were for sleeping tablets and Elastoplast. Body-weights, as shown in Table I, remained remarkably constant and at the finish the whole party felt very fit. The most exhausting factors, of which everyone was glad to be free, were the $24 \mathrm{~h}$ of daylight and the 6 weeks of pent-up nervous tension resulting from the uncertainties of mountaineering and living constantly amidst crevasse-ridden glaciers.

\section{DISCUSSION}

The provisioning of mountaineering and other expeditions in the field is still very arbitrary and empirical. However, renewed interest in recent years in the physiology of nutrition and a spate of postwar expeditions of exploration have led to a steadily increasing accumulation of information on the subject.

The longest period for which the calorie intake of a mountaineering expedition has been recorded is the 18 days during the approach march of the $195^{2}$ Himalayan expedition to Cho Oyu (Pugh, 1953) and for further periods on the same expedition of up to Io days at an altitude of over $15,000 \mathrm{ft}$. $(4500 \mathrm{~m})$. Calorie expenditure for these periods was simultaneously estimated (Table 7).

It is inevitable that any estimate of energy expenditure by indirect calorimetry and diary technique whilst climbing under widely varying conditions can only be very approximate. Indeed, it has been found that the energy expenditure of the same individual climbing under the same set of conditions can vary up to $20 \%$ on different occasions (Durnin, 1955).

On the successful I953 Everest expedition, an approximate estimate of food consumption was made for the various stages of the approach march and assault; no record, however, was kept of food wasted, save by Ward who, at an altitude of over $21,000 \mathrm{ft}$. $(6300 \mathrm{~m})$, recorded exactly over a period of 2 days the food consumed by himself and his companion, an intake of $2600 \mathrm{Cal} / \mathrm{man} /$ day (Pugh, 1954). Shipton 
Vol. I3
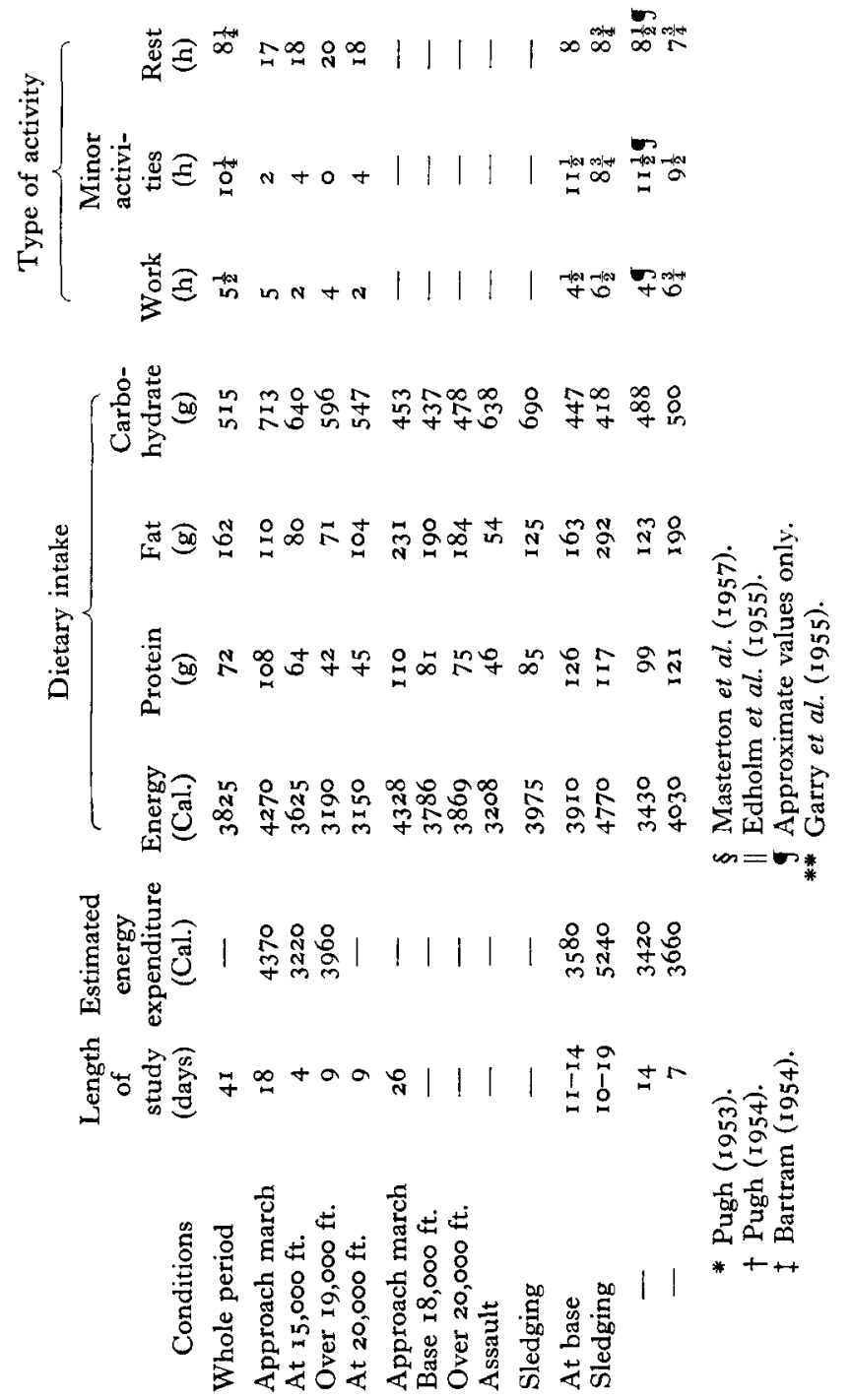

$\dot{1}$

$\frac{\pi}{\frac{\pi}{\pi}}$

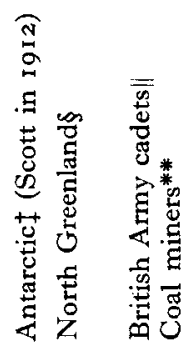


(1938), on the 1935 Everest expedition, estimated the calorie intake of the climbers at an altitude between $17,000 \mathrm{ft}$. $(5100 \mathrm{~m})$ and $21,000 \mathrm{ft}$. $(6300 \mathrm{~m})$ to be approximately 2000 Cal. During glacier exploration on the 1954 North Greenland expedition, estimates were made of the food intake and energy expenditure of two sledging parties (Masterton, Lewis \& Widdowson, 1957). Each party consisted of two men, and estimates were made over periods of 10 and I9 days respectively. The mean calorie intake was $4770 \mathrm{Cal} / \mathrm{man} / \mathrm{day}$. The mean daily energy expenditure was calculated to be $5240 \mathrm{Cal} / \mathrm{man}$, but direct energy measurements were made of the basal metabolic rates only. Estimates at their base camp, over two periods totalling $\mathrm{I}^{\mathrm{I}-\mathrm{I} 4}$ days, showed a mean daily calorie intake of $3910 \mathrm{Cal}$. and a calculated expenditure of $35^{80}$ Cal.; no heavy work was done, but the environmental temperatures were constantly below $0^{\circ} \mathrm{C}$. Similar studies have recently been carried out on the Commonwealth Antarctic Expedition. Welch, Mann, Insull, Friedemann, Buskirk, Kreide, Brebbia, Morana \& Daniels (1955) studied the calorie balance of eight U.S. soldiers during a 12-day period of bivouacking (meals being eaten indoors) at temperatures below $-25^{\circ} \mathrm{F}\left(-32^{\circ} \mathrm{C}\right)$. Each day $5 \mathrm{~h}$ of travel over snow was done with sledgehauling and load carrying. The maximum individual calorie requirement, based on food intake and corrected for weight loss, was estimated to be $4260 \mathrm{Cal}$.

After studies of twenty-six U.S. soldiers over a period of 3 weeks, Welch, Levy, Consolazio, Buskirk \& Dee (1957) recommended a maximum calorie intake of 4500 Cal./day for men in an Arctic environment. They also stated that, provided a man is properly clothed, his calorie requirements appear to be proportional to the work he is doing and not to the temperature of his environment, although low temperatures will of themselves encourage activity.

As our Alaskan expedition studies lasted for 6 weeks, it was possible to eliminate many of the inaccuracies that occur in estimating calorie intake over shorter periods. Although it was not possible to measure the exact energy expenditure, the fact that there was no rapid gain or loss of weight by any member of the party suggests that over the whole period of the expedition each individual was in calorie balance, but not necessarily in daily balance. This balance implies that the calorie intake was adequate.

It may be seen from Table 7 that the calorie intake during the approach to the mountains was lower than that of other expeditions; even between $9000 \mathrm{ft}$. ( $1700 \mathrm{~m})$ and $\mathrm{r}_{3}, 000 \mathrm{ft}$. $(3900 \mathrm{~m})$ in Alaska, the intake was as low as or lower than the Cho Oyu and Everest estimates at over $20,000 \mathrm{ft} .(6300 \mathrm{~m})$. The calorie intake for the latter expeditions, however, was estimated from the rations issued, but these were not necessarily wholly consumed. The Alaskan estimate of calorie requirements was also considerably lower than that of Masterton et al. (1957) for the North Greenland sledging parties, although there was not a great difference in the time spent in the major activities. It would also seem doubtful whether energy expenditure of the order suggested by Durnin (1955) was ever reached. He calculated an expenditure of $5900-7300$ Cal. for a $7 \mathrm{~h}$ ascent and $3 \mathrm{~h}$ descent with a load. The longest climb in Alaska involved i $\mathrm{h}$ ascent and $7 \mathrm{~h}$ descent with $30 \mathrm{lb}$. ( $33 \mathrm{~kg}$ ) loads.

It is of interest to speculate how much the availability of food is in itself a key factor in determining how much food is consumed from day to day of an expedition. 
As the four-man Alaskan expedition had to transport all its own supplies without the assistance of porters or dog teams, all loads were cut to the absolute minimum, thus artificially creating a limited value for the possible food intake. However, the entire party was of the opinion that on most occasions the overall diet was adequate, if not generous, even if individual taste was not always catered for. In what way the sensations of appetite and hunger are related to energy expenditure is uncertain, but on the Alaskan expedition these sensations were, in the main, subordinated to necessity and satisfied only when food supplies would permit. Calorie balance was not achieved by the satisfying of appetite, but artificially by the distribution of rations.

All four climbers performed almost identical activities throughout the 6 weeks, and individual variation in calorie intake must therefore be accounted for by differences in physique and skill and hence the rate of energy expenditure. W. D., the most heavily built, did not appear to consume the greatest amount of food, although his intake differed little from that of D.K. and D.P. On the other hand, J.M., the lightest in weight, consistently had an intake of between I00 and $400 \mathrm{Cal}$. below that of the others. This finding suggests that the dietary intake of W.D. and J. M. was adequate and provides further grounds for supposing that the intake of the whole party was probably adequate.

It is desirable in any expedition in the field that rations should conform to certain specifications, providing adequate nutrition with as little expense, weight and bulk, as possible. That these criteria are not fulfilled on many expeditions is often very noticeable. The proportion by weight of food to other equipment is always considerable, and in the Alaskan expedition food comprised one-half of the total weight; yet rations had been cut to a minimum with only a very small reserve to provide for unexpected contingencies.

After careful consideration of the desirable features of the ration and of the environment in which it is to be used, a compromise may have to be made in deciding its composition. On a climbing expedition it is necessary to provide the largest meal at the end of the day; breakfast must be speedily cooked and it must be possible to consume the snack lunch en route without cooking.

Table 8 compares the rations used on various expeditions and in the British Army. It is suggested that the standard expedition ration (types $\mathrm{A}, \mathrm{B}, \mathrm{C}$ and $\mathrm{D}$ ) with certain modifications, especially in the protein content, and supplemented by a few luxury items, fulfils the requirements for provisioning an expedition in the field. It compares very favourably with rations used on other expeditions and would be suitable for any other intended mountaineering expedition or for isolated units of the Armed Forces in the field, after suitable instruction in its use. This ration would overcome the major difficulties of cost, bulk and handling in the field.

\section{SUMMARY}

I. Records were made of the individual calorie intakes of a four-man Alaskan mountaineering expedition over a period of 6 weeks. The mean intake for the whole period was found to be 3825 Cal. daily. 
2. The daily activities of the expedition are described. The mean time spent daily in major physical activities was $5 \frac{1}{2} \mathrm{~h}$, in minor activities $10 \frac{1}{4} \mathrm{~h}$ and in resting $8 \frac{1}{4} \mathrm{~h}$. These times are compared with those of other expeditions and of two active occupations.

3. It is concluded that, as body-weights remained fairly constant, the four men were in approximate calorie balance, and that for the period of the expedition calorie intake provided an estimate of energy expenditure.

4. The principles of provisioning a small expedition in the field are outlined, and a suitable ration is described.

5. The dietary intake and energy expenditure for various expeditions in the field are compared.

I should like to thank Captain E. J. E. Mills, the leader of the expedition, and my two other climbing colleagues, for their co-operation and tolerance; I am also most grateful to Professor R. C. Garry and Dr J. V. G. A. Durnin of the Institute of Physiology, Glasgow University, for much helpful advice and encouragement.

\section{REFERENCES}

Bartram, J. C. L. (1954). Proc. Nutr. Soc. 13, 69.

British Medical Association: Committee on Nutrition (1950). Report of the Committee on Nutrition. London: British Medical Association.

Durnin, J. V. G. A. (1955). F. Physiol. 128, 294.

Edholm, O. G., Fletcher, J. G., Widdowson, E. M. \& McCance, R. A. (1955). Brit. F. Nutr. 9, 286.

Evans, C. E. (1956). Kangchenjunga: The Untrodden Peak. Appendix B, by G. C. Band. London: Hodder and Stoughton.

Garry, R. D., Passmore, R., Warnock, G. M. \& Durnin, J. V. G. A. (1955). Spec. Rep. Ser. med. Res. Coun., Lond., no. 289 .

Lewis, H. E. \& Masterton, J. P. (1957). Lancet, 272, 1262.

Masterton, J. P., Lewis, H. E. \& Widdowson, E. M. (1957). Brit. F. Nutr. II, 346.

Medical Research Council: Accessory Food Factors Committee (1945). M.R.C. (War) Memor. no. I4.

Mills, E. J. E. (1957). Alpine 7. 62, 121.

Ministry of Food (195I). Private communication.

Pugh, L. G. C. (1953). Food Consumption and Energy Balance at Various Altitudes. London: Allen and Unwin.

Pugh, L. G. C. (1954). Proc. Nutr. Soc. 13,60.

Shipton, E. (1938). Chem. Eீ Ind. 57, 1231 .

Smith, H. G. (1954). Proc. Nutr. Soc. 13, 45.

Welch, B. E., Mann, J. B., Insull, W., Friedemann, T. E., Buskirk, E. R., Kreide, M., Brebbia, R., Morana, N. \& Daniels, F. (1955). U.S. Army. Med. Nutr. Lab. Rep. no. 173.

Welch, B. E., Levy, L. M., Consolazio, C. F., Buskirk, E. R. \& Dee, T. E. (1957). U.S. Army. Med. Nutr. Lab. Rep. no. 202. 